\title{
A study of the scale insect genera Puto Signoret (Hemiptera: Sternorrhyncha: Coccoidea: Putoidae) and Ceroputo Šulc (Pseudococcidae) with a comparison to Phenacoccus Cockerell (Pseudococcidae)
}

\author{
D.J. WILLIAMS ${ }^{1}$, P.J. GULLAN ${ }^{2,3,6}$, D.R. MILLER ${ }^{4}$, D. MATILE-FERRERO ${ }^{5} \&$ SARAH I. HAN $^{2}$ \\ ${ }^{\prime}$ Department of Entomology, The Natural History Museum, Cromwell Road, London, SW7 5BD, U.K. \\ ${ }^{2}$ Department of Entomology, University of California, One Shields Avenue, Davis, CA 95616, U.S.A. E-mail: pjgullan@ucdavis.edu \\ ${ }^{3}$ Division of Evolution, Ecology and Genetics, Research School of Biology, The Australian National University, Canberra, A.C.T., \\ 0200, Australia. E-mail: penelope.gullan@anu.edu.au \\ ${ }^{4}$ U.S. Department of Agriculture, Systematic Entomology Laboratory, PSI, Agricultural Research Service, Building 005, Barc-West, \\ 10300 Baltimore Avenue, Beltsville, MD 20705, U.S.A. E-mail: Douglass.miller@ars.usda.gov \\ ${ }^{5}$ Muséum national d'Histoire naturelle, Département Systématique et Évolution, UMR 7205, MNHN-CNRS, Entomologie. 45, rue Buf- \\ fon, CP 50, F-75231 Paris Cedex 05, France. \\ ${ }^{6}$ Corresponding author: E-mail: pjgullan@ucdavis.edu
}

\begin{abstract}
For almost a century, the scale insect genus Puto Signoret (Hemiptera: Sternorrhyncha: Coccoidea) was considered to belong to the family Pseudococcidae (the mealybugs), but recent consensus accords Puto its own family, the Putoidae. This paper reviews the taxonomic history of Puto and family Putoidae, compares the morphology of Puto to that of Ceroputo Šulc and Phenacoccus Cockerell, and reassesses the status of all species that have been placed in Puto to determine whether they belong to the Putoidae or to the Pseudococcidae. For 49 of 57 species that have been placed in Puto, as listed in the online database ScaleNet, we score and tabulate features that are diagnostic for Putoidae and then list all species in their correct family placement. For comparison, we include a few species of Pseudococcidae, namely five species of Phenacoccus, including the type species Phenacoccus aceris (Signoret), and the type species of Ceroputo, C. pilosellae Šulc. We provide revised synonymy lists for Puto and Ceroputo, a brief diagnosis of each genus, synonymy lists and notes for several species for which we suggest recombinations or additional synonyms, or for which we have additional data on morphology. We provide a brief diagnosis of Phenacoccus for comparison with Ceroputo and Puto. As a result of our study, we recognise 47 extant and two fossil species of Puto, and six species of Ceroputo. The New World species Puto mimicus McKenzie and Puto nulliporus McKenzie are transferred to the mealybug genus Ceroputo as Ceroputo mimicus (McKenzie) comb. nov. and Ceroputo nulliporus (McKenzie) comb. nov., respectively, and the Old World species Puto pini Danzig and Puto vaccinii Danzig are recognised as Ceroputo pini (Danzig) comb. rev. and Ceroputo vaccinii (Danzig) comb. rev., respectively, in agreement with Tang (1992). The Old World species Puto graminis Danzig is transferred to Ceroputo as Ceroputo graminis (Danzig) comb. nov. Based only on a study of the literature, the following two names are treated here as junior subjective synonyms of Ceroputo pilosellae: Phenacoccus asteri Takahashi syn. nov. and Puto jarudensis Tang syn. nov. We agree with Tang (1992) that Leococcus erigeroneus Kanda should be treated as a junior subjective synonym of $C$. pilosellae and thus the genus name Leococcus Kanda, erected for L. erigeroneus and formerly treated as a junior synonym of Puto, is a junior synonym of Ceroputo.
\end{abstract}

Key words: archaeococcoids, neococcoids, mealybug, taxonomy

\section{Introduction}

The name Puto, proposed by Signoret (1876), was a replacement name for the occupied name Putonia Signoret, a genus described for the single species Putonia antennata Signoret from France by Signoret (1875). At present, the genus Puto has a distribution comprising the Palaearctic Region (with an extension into the Oriental Region) and the New World (ranging from near the Arctic Circle to the Neotropical Region). Old World and New World species 
have not overlapped until recently when Puto barberi (Cockerell), a common species in the Caribbean area (Williams \& Granara de Willink, 1992), was introduced accidentally into Gran Canaria, Canary Islands, and now occurs there on many ornamental plants (Malumphy, 2010). The species is listed by Miller et al. (2002) as a possible invasive species and a threat to U.S. agriculture.

Females and immature males of Puto resemble mealybugs, family Pseudococcidae, and especially some species of Phenacoccus Cockerell. Adult females of Phenacoccus and Puto are similar in possessing 18 basic pairs of cerarii, usually 9-segmented antennae, ostioles, and often a circulus. For almost 100 years, species of Puto have been included among the Pseudococcidae, and even today, the genus often is included within the Pseudococcidae for convenience. The family placement of Puto has been confused further by the inclusion of some species that really are mealybugs, as we document later in this paper. It has long been known, however, that adult males of Puto possess a row of unicorneal eyes encircling the head plus a pair of ocelli (Reyne, 1954; Beardsley, 1962), whereas adult males of species of Pseudococcidae have only a dorsal and ventral pair of unicorneal eyes and a pair of ocelli (Theron 1958; Giliomee, 1961; Afifi, 1968). Beardsley (1969) was the first to place Puto in its own family, Putoidae, based on male features, and this action has gained wide recognition now (e.g., Hodgson \& Foldi, 2006; Gullan \& Cook, 2007).

In a paper on the evolution and phylogeny of the Coccoidea, Borchsenius (1958) proposed two major branches of scale insects, the Archaeococcoidea and Neococcoidea. He included the families Margarodidae, Ortheziidae and Phenacoleachiidae in the Archaeococcoidea, whereas all the other families recognised at the time were included in the Neococcoidea. The names 'Archaeococcoidea' and 'Neococcoidea' are not based on nominal genera, and thus these informal groups are now referred to as archaeococcoids and neococcoids, as explained in the review by Gullan and Cook (2007). The family Margarodidae as recognised by Borchsenius was that defined by Morrison (1927, 1928), and included most of the presently recognised archaeococcoid families. The archaeococcoids therefore, comprise families in which adult males have either compound or multifaceted eyes, or a row of unicorneal eyes encircling the head. Furthermore, all the archaeococcoids recognised by Borchsenius (1958), possess abdominal spiracles in at least the females, whereas abdominal spiracles are absent from all taxa of neococcoids. The genus Puto was not mentioned in Morrison (1928) and would have been included in the family Pseudococcidae by Borchsenius (1958), and thus treated as a neococcoid genus.

Other archaeococcoid families with species for which adult males possess a row of unicorneal eyes are the extant families Pityococcidae, Steingeliidae, and Phenacoleachiidae (Hodgson \& Foldi, 2006). The three fossil families Electrococcidae, Grimaldiellidae and Kukaspididae (Koteja, 2000; Koteja \& Poinar, 2001) also have adult males with a row of unicorneal eyes, and Koteja and Azar (2008) added the fossil genus Palaeotupo Koteja and Azar, to the family Putoidae. This genus also possesses a row of unicorneal eyes. Neococcoid groups that include species with adult males that have more than the dorsal and ventral eyes are the family Kermesidae (Sternlicht, 1969; Koteja \& Zak-Ogaza, 1972; Miller \& Miller, 1993a) and several genera of the family Coccidae (Giliomee, 1967; Miller \& Williams, 2002; Hodgson \& Henderson, 2004).

Another male character of interest is the number of lateral filaments on the posterior end of the abdomen. Adult males of Puto possess a single pair (Beardsley 1962; Miller \& Miller 1993b), whereas species of Ceroputo Šulc and Phenacoccus (and some other genera of the mealybug subfamily Phenacoccinae) have two pairs (Afifi, 1968; Beardsley, 1960; Miller, 1975; Hardy et al., 2008). Most other pseudococcid males have a single pair of lateral filaments or lack them entirely (Afifi, 1962; Beardsley, 1962).

The correct placement of the family Putoidae has been a problem since it was first erected. Despite being defined as having a row of unicorneal eyes encircling the head of the adult male, insects of the family lack abdominal spiracles, a feature characteristic of archaeococcoids. Based on a study of the labium, Koteja (1974a) placed Puto (under its junior synonym Macrocerococcus Leonardi) in the subfamily Trabutininae of the family Pseudococcidae. In a later paper, Koteja (1974b) treated the family name Putoidae as a junior synonym of Trabutininae. Many of the Palaearctic species of Puto were included in the tribe Phenacoccini of the family Pseudococcidae by Danzig (1980), and Tang (1992) placed Puto together with several mealybug genera in the tribe Putoini of the subfamily Phenacoccinae. Miller and Kosztarab (1979) regarded Puto as belonging to the more 'primitive' groups of scale insects in which high mobility is associated with well-developed legs possessing numerous setae, but they still placed the genus among the neococcoids. Although Miller (1984) regarded the Putoidae as a well-defined group, separate from the Pseudococcidae, he continued to place Puto among the neococcoids. In a phylogenetic analysis based on morphology, Miller and Miller (1993b) preferred Puto to be included in the Pseudococcidae but 
conceded that the group has unique morphological features. According to Koteja (1996), all neococcoids are descendants of the putoid lineage, but this view has not been supported. Most recently, phylogenetic analyses based on nucleotide sequence data have shown clearly that Puto does not belong to the Pseudococcidae (Cook et al., 2002; Gullan \& Cook, 2007; Hardy et al., 2008). In a preliminary phylogenetic study of non-"margarodid" adult males, Hodgson (2002) suggested that the Putoidae and Phenacoleachiidae might be closely related. He considered that their lack of compound eyes and the absence of abdominal spiracles in the Putoidae made their position in the archaeococcoids questionable. Later, Hodgson and Foldi (2005) studied adult males of the family Margarodidae sensu Morrison (1928) and found that the families Phenacoleachiidae and Putoidae together with Steingelia Nasonov [Steingeliidae], Pityococcus McKenzie [Pityococcidae] and the Pseudococcidae formed a clade, but apart from some male mealybugs, no other neococcoid families were included in the analysis. Hodgson and Foldi (2006), in a remarkable contribution describing adult males, considered Putoidae to belong to a group of families that also contains Phenacoleachiidae, Pityococcidae and Steingeliidae.

Most archaeococcoids have a XX-XO sex chromosome system (Hughes-Schrader, 1948; Nur, 1980) and this is also true for Puto (Hughes-Schrader, 1944). This system is an ancestral type for scale insects (Nur, 1980). However, in all neococcoids there is a paternal genome elimination (PGE) system (with a few rare exceptions that are considered secondary changes), in which the paternal genome is deactivated through heterochromatisation (Nur, 1980; Normark, 2003; Yokogawa \& Yahara, 2009; Ross et al., 2010). Based on molecular studies, Cook et al. (2002) and Gullan and Cook (2007) showed that the Putoidae along with Phenacoleachiidae, Pityococcidae and Steingeliidae are placed outside the neococcoids and firmly within the archaeococcoids, although evidence for the monophyly of the archaeococcoids was lacking. If the Putoidae and the Phenacoleachiidae are related, as suggested by data from adult males, then these groups must have diverged from the ancestor of the neococcoids before the evolution of PGE in the latter. The oldest fossil tentatively assigned to Putoidae is from the Lower Cretaceous (125-135 mya) (Koteja \& Azar, 2008).

In addition to the uncertainty concerning the relationships of Puto to other scale insects, there has been controversy over the generic and thus family placement of some species that currently are placed in Puto. The genus names Ceroputo and Macrocerococcus have been treated as subjective synonyms of Puto, although Tang (1992) recognised the genus Ceroputo as distinct from Puto in his study of Chinese mealybugs. Hardy et al. (2008) formally resurrected Ceroputo from synonymy with Puto based on morphological assessment of the type species of both genera. Hardy et al. (2008) also suggested that the species of Puto should be studied morphologically to determine which belong to Putoidae and which to Pseudococcidae.

The main purpose of this study is to decide which of the species presently included in the genus Puto belong to the Putoidae and which belong to the Pseudococcidae. We have examined authentic specimens (types wherever possible) and original descriptions of the species assigned to Puto in ScaleNet, an online database of scale insects (Ben-Dov et al. 2010) (referred to as "ScaleNet" in the rest of the paper). Here we discuss the morphological features that are diagnostic for Putoidae and score most species for these features to determine their family placement and to provide a revised list of species that genuinely belong to Puto.

\section{Material and methods}

Specimens of almost all the species presently included in the genus Puto, based on ScaleNet records, have been examined to determine their family placement. For a small number of species for which specimens were unavailable, descriptions and illustrations were used to decide on the correct placement of the species. Adult female specimens of 49 of the 57 species that have been listed in Puto in ScaleNet were available for study, but fewer first-instar nymphs and adult males were available. Wherever possible we examined type specimens (available for 41 species) and, if one or more types were studied, this is indicated after the species names in Table 1. If specimens in addition to types were used, a "+" is given after the species name in Table 1 . The morphological terms used are the same as those in Williams (2004). The morphological features that we studied were selected based on their known or suspected distinction between Puto and mealybugs, or their known variation among species of Puto. These features are discussed in detail in the next section. All specimens were scored for states of the following morphological characters: 
1. Number of campaniform sensilla on each surface of trochanter of adult female

2. Presence or absence of basal spurs on claw of adult female

3. Number of antennal intersegmental sensilla between segments III-IV, IV-V and VI-VII of adult female

4. Presence or absence of club on claw digitules of hind legs (i.e. capitate or not) of adult female. If the digitules could not be seen on the hind legs, other legs were used to make a determination.

5. Presence or absence of club on tarsal digitules of hind legs (i.e. capitate or not) of adult female. If the digitules could not be seen on the hind legs, other legs were used to make a determination.

6. Presence or absence of long tubular ducts on frons of adult female

7. Number of antennal segments of first-instar nymph

8. Number of unicorneal eyes on head of adult male

9. Shape of tip of aedeagus of adult male, either simple or bifid.

We have studied specimens housed in: the Bohart Museum of Entomology, University of California, Davis, California, U.S.A. (BME); Department of Entomology, The Natural History Museum, London, UK (BMNH); Departement d'Entomologie, Muséum national d'Histoire naturelle, Paris, France (MNHN); Zoological Institute, St Petersburg, Russia (ZISP); and the United States National Museum of Natural History, slide collections at USDA, Beltsville, Maryland, U.S.A. (USNM). The depositories for type specimens of the species can be obtained from ScaleNet and are not listed here.

\section{Morphological features of Puto and comparisons with Pseudococcidae and other families}

Adult males. Adult males of Putoidae are easily distinguishable from adult males of Pseudococcidae by the presence of a row of 8-15 unicorneal (or simple) eyes encircling the head plus a pair of ocelli, whereas Pseudococcidae possess only dorsal and ventral pairs of unicorneal eyes and a pair of lateral ocelli. For instance, the adult male of the type species of Puto, P. antennatus (Signoret) has 12 unicorneal eyes (Reyne, 1954). In contrast, the adult male of the type species of Ceroputo, C. pilosellae Šulc (based on specimens from Fragaria vesca from Belgrade, Yugoslavia [Serbia]), was described by Afifi (1968) as having a pair of dorsal and a pair of ventral simple eyes plus a pair of lateral ocelli. Also, adult males of Putoidae are separable from other families in which the adult male has a row of unicorneal eyes, in that the ocular sclerite of males of Puto almost forms a complete band around the head and nearly touches in the middle on the dorsum and venter (Reyne, 1954; Beardsley, 1962; Hodgson \& Foldi, 2006). In some species of Puto, the sclerotisation on the venter of the head is restricted to the area next to the eyes (Washburn, 1965; Miller \& Miller, 1993b). The adult males of most, but not all, archaeococcoid families have abdominal spiracles, but spiracles have not been detected in adult males of Puto (Hodgson \& Foldi, 2006). Microtrichia are present on the wings in the Putoidae and the Phenacoleachiidae (Koteja, 1996; Hodgson \& Foldi, 2006), a feature not shared with other archaeococcoids but present in neococcoids. Some setae on the antennae of adult males of Putoidae have associated basal setae (Miller \& Miller, 1993b). Similar setae are present on the antennae of adult males of Phenacoleachiidae and another archaeococcoid family, the Xylococcidae (Koteja, 1996). Miller and Miller (1993b) suggested that there are two main groups of Puto, one on conifers with adult males having a short, non-articulated aedeagus with a simple tip, and the other group on non-coniferous host plants having males with a long articulated aedeagus with a bifid tip.

Adult females. Although adult females of Putoidae bear a superficial resemblance to adult female mealybugs (Pseudococcidae), there are several differences that have been known for some time, but rarely have been investigated fully. We discuss these features in the following sections.

Antennae (Fig. 1A). The antennae of Puto are normally 9-segmented, rarely 8-segmented (P. caucasius has 8 segments with the third one about twice as long as the other segments (Danzig, 1999)). As discussed by Koteja (1980), antennal intersegmental sensilla are present on the membranous areas between certain segments in certain scale insect taxa, with their nature, number and position varying among species. He showed that representatives of each of six genera of Pseudococcidae had these sensilla in one position only, whereas an unidentified species of Heliococcus Šulc [a genus related to Phenacoccus and placed in the subfamily Phenacoccinae by Hardy et al. (2008)] and some, but not all, archaeococcoid taxa had more numerous intersegmental sensilla. In Puto, these sensilla are usually minute structures, each with a basal socket or collar, and a slightly raised central part, but in other 
groups of scale insects the central part can be seta-like. In Puto, these sensilla occur in varying numbers from 0-4 on each of the membranous areas between segments III-IV, IV-V and VI-VII (Table 1). They are never present between segments V-VI. In one or two species, we have not observed them between segments VI and VII, e.g. Puto graminis, but sometimes we have only been able to study one or two specimens of each species. Occasionally, we have not observed these sensilla on one or more membranous areas on a single antenna but they are present on the other antenna. We have not seen a specimen of Puto entirely without these sensilla, and their presence was used, in combination with other features, as a distinguishing characteristic for Puto by Hardy et al. (2008), although those authors referred to the sensilla as interflagellar setae. In the type species of Ceroputo, C. pilosellae, intersegmental sensilla can occur between segments III-IV, IV-V and VI-VII, as in Puto, but the sensilla are not consistently present in this species. We have studied a few species of Phenacoccus (family Pseudococcidae), including the type species Ph. aceris (Signoret) (Table 1), and found that these sensilla are usually present between segments VI and VII (in 9-segmented antennae) but never in other locations on the antennae. The occurrence of these sensilla has not been studied in over 200 species now placed in Phenacoccus.

The number of antennal segments in first-instar nymphs of Puto is seven (Reyne, 1954; Washburn, 1965; Miller, 1991), although the first-instar nymphs of P. caucasicus can have six or seven (I.A. Gavrilov, pers. comm.). In all mealybugs (Pseudococcidae), the number of antennal segments in first-instar nymphs is six at most (Miller, 1991).

Legs (Fig. 1B). The legs of females of Puto are well developed and heavily sclerotised, and often longer relative to body size than those of the family Pseudococcidae except some specialised mealybug genera such as Leptococcus Reyne and Macrocepicoccus Morrison. Moreover, the legs of adult females of Puto usually contain many more setae than those of female pseudococcids. Small sensilla on the trochanters in mealybugs and other scale insects have been illustrated often in the past, and Koteja (1974c) and De Lotto (1979) discussed them in detail. The position of these sensilla suggests a mechanical function in detecting stresses on the cuticle resulting from movement of the legs and thus these structures are most likely to be campaniform sensilla (or sensilla campaniformia), rather than the similar-looking sensilla placodea. The latter have an olfactory or gustatory function and typically occur on the antennae and mouthparts of insects, whereas campaniform sensilla have a mechanical function (Zacharuk \& Shields, 1991). In almost all mealybugs (including Ceroputo and Phenacoccus) there are two campaniform sensilla on each surface of each trochanter, and these are often called trochanteral pores or sensory pores. In Puto, there are usually three such sensilla on each surface of each trochanter, sometimes four (Fig. 1B, i \& ii), but occasionally they are reduced to two on some trochanters. If only two are present, this number is restricted to only one or two trochanters on any one specimen and there are always more than two present on some trochanters in any single specimen (Table 1). In the Pseudococcidae, the only species known to possess three sensilla on each surface of the trochanters is the African Lenania prisca De Lotto, discussed by De Lotto $(1964,1979)$.

A single campaniform sensillum (sensory pore) is always present at the proximal end of the tarsus in Puto, in common with most scale insects (Koteja, 1974c). On the adult female of Puto species, this sensillum is just a slight swelling distad of the sclerosis between the tibia and tarsus, but is more obvious on the third-instar female.

Apparently unique to Puto is a pair of spurs at the base of the claw, here referred to as basal spurs (Fig. 1B, iii). These are present in most species, but we have examined some species in which they appear to be absent and they are sometimes present or absent in specimens from any one collection of the same species. However the apex of the leg has to be oriented in a certain way on the slide-mount to see these spurs clearly and thus the failure to see the spur on some legs or specimens is not to be taken as meaning that they are absent. Furthermore, the spurs are often lightly sclerotised and can be damaged by prolonged treatment in potassium hydroxide. These basal spurs are without collars or sockets and they seem to be outgrowths of the claw, pointing downwards so that when the plantar surface of the claw is in contact with a surface, they must have contact with the surface also. Somewhat similar structures are present on the adult females of some Coccidae - cf. Macropulvinaria, although they are smaller, sclerotised and represented by only one projection rather than a pair (C.J. Hodgson, pers. comm.). The basal spurs are present in addition to the normal digitules. The knobs on the claw digitules and tarsal digitules may be present or absent and we have indicated this in Table 1 whenever possible. The digitules in Puto appear to be quite normal and resemble those in the Pseudococcidae. In Phenacoleachia zealandica (Maskell) (Phenacoleachiidae), one of the claw digitules is normal but the other resembles a short blunt spur (Gullan \& Cook, 2002). Koteja (1996) suggested that this modified digitule in Phenacoleachia may be a vestigial claw but this is doubtful. 
Cerarii. All species of Puto possess at least 18 pairs of marginal cerarii, each with multiple setae, all on sclerotised plate-like areas [those in P. thailandicus Williams appear to be on weakly-sclerotised areas (Williams, 2004)]. Ceroputo pilosellae similarly has 18 pairs of cerarii, each on a sclerotised area. Some species of Phenacoccus are similar in this respect except that the cerarii are usually on membranous areas. Puto superbus (Leonardi) possesses as many as 26 pairs of marginal cerarii in the adult female and there are varying numbers above 18 pairs in some other species. The increase in number, however, is due to division of existing cerarii and this division occurs also in the third-instar females and sometimes in second-instar nymphs of both sexes. The basic number of 18 pairs is always shown in first-instar nymphs. Wide tubular ducts are present within the cerarii in some species from both the New World and Old World.

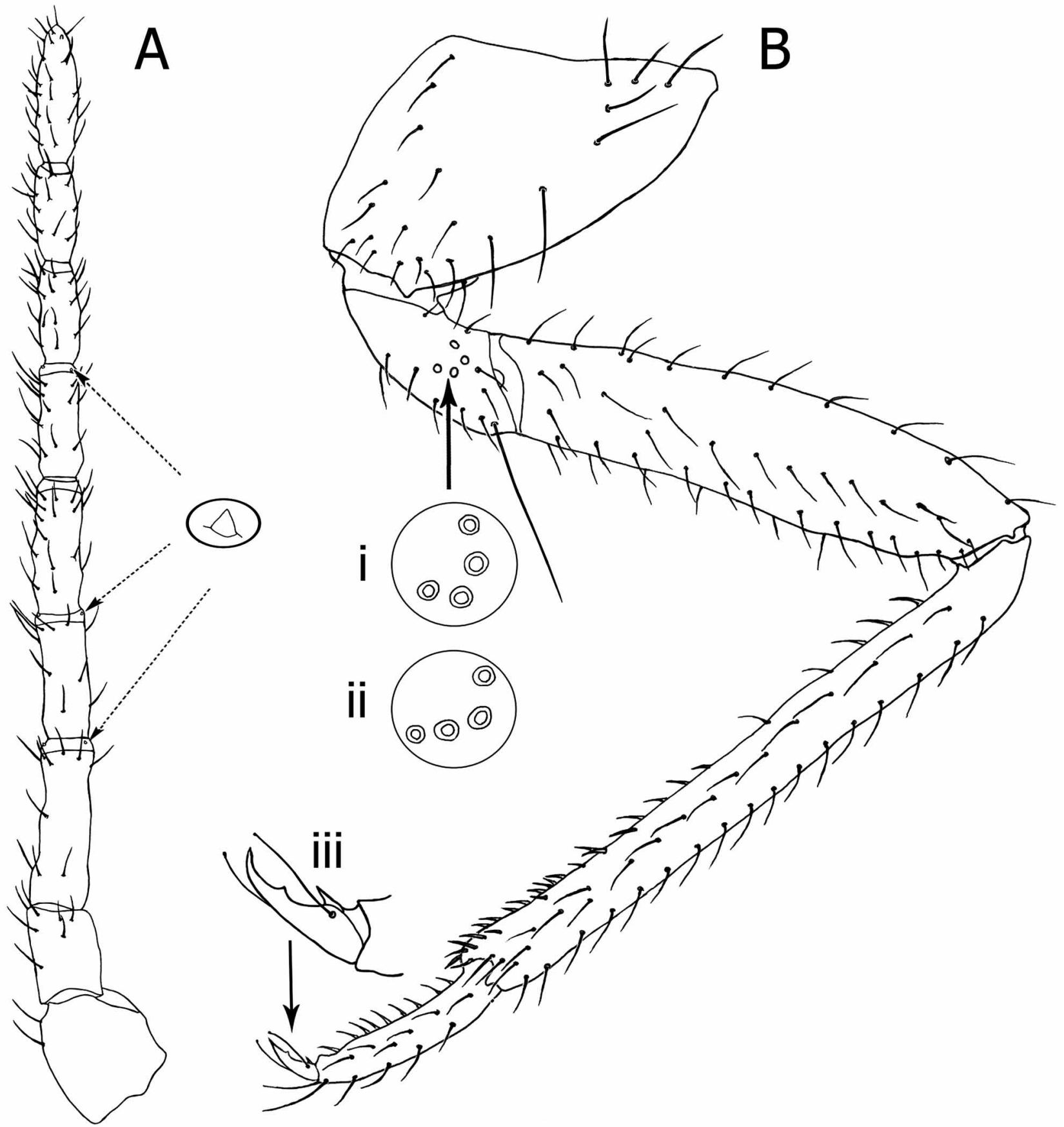

FIGURE 1. Diagnostic features of Puto as exemplified by the adult female of $P$. albicans McKenzie: (A) An antenna with pairs of intersegmental sensilla in the membranes between segments III-IV, IV-V and VI-VII, and (B) a hind leg with enlargements of the four campaniform sensilla on the (i) ventral and (ii) dorsal surfaces of the trochanter, and (iii) an enlargement of the claw showing the basal spur and claw digitules of one side (drawing by S.I. Han). 


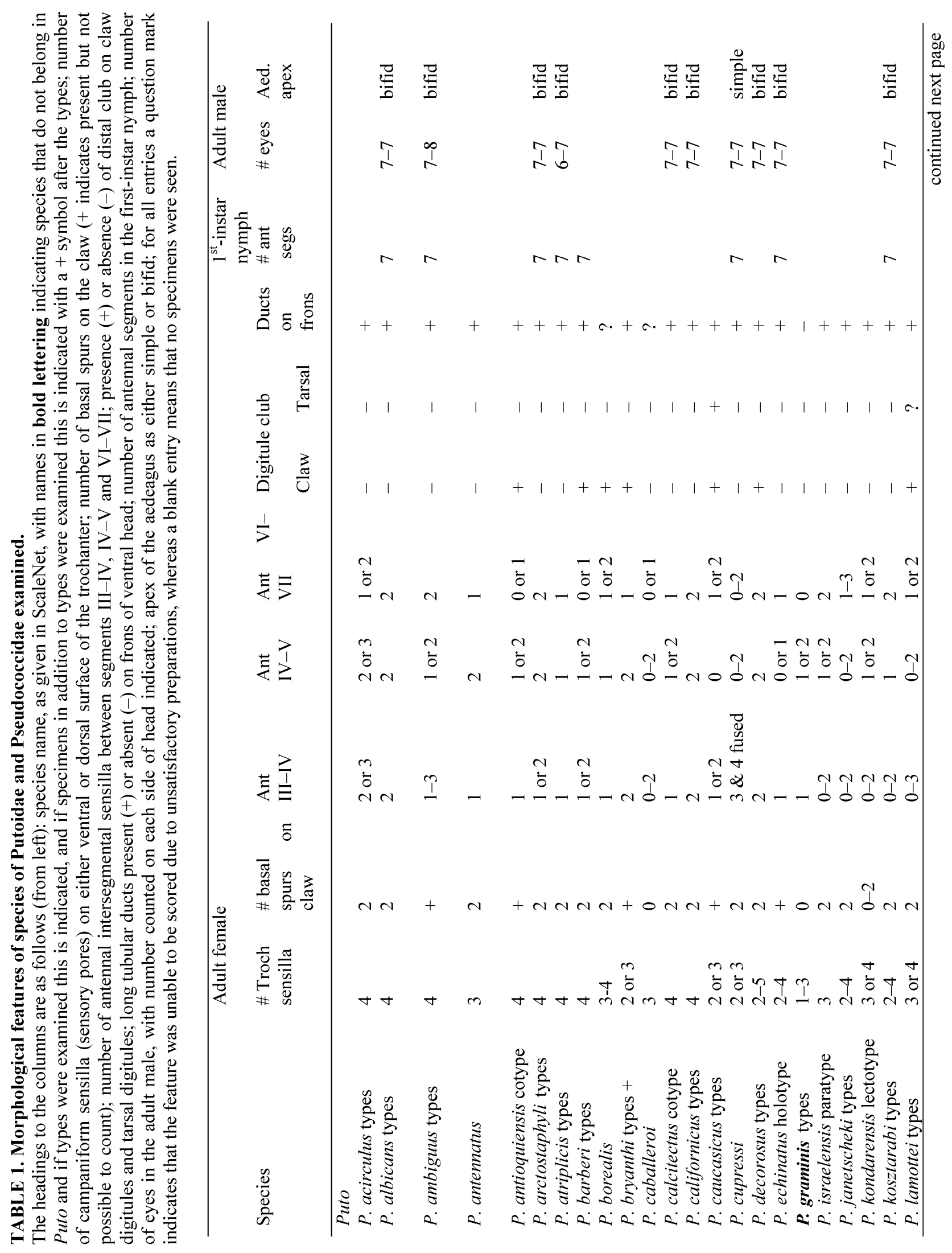




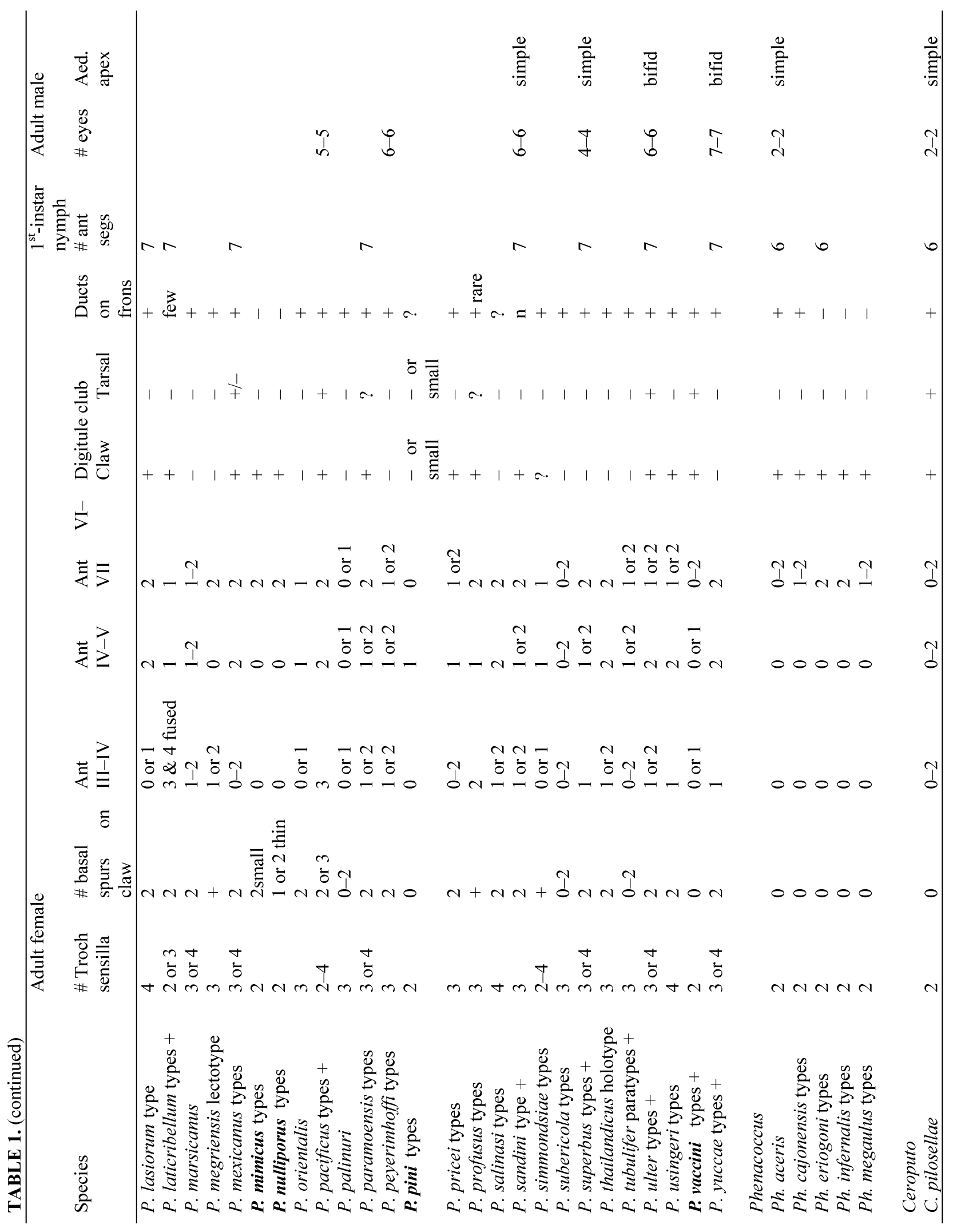


Tubular ducts. On adult females of Puto, the oral collar tubular ducts occur only on the venter except in a few species with wide ducts within the marginal cerarii and/or scattered over the dorsum. In most species of Puto, there is a group of ducts on a concave, wrinkled or cushion-like area on the frons just anterior to the clypeolabral shield, which is usually devoid of setae. In most species, these ducts are longer and more slender than the ducts elsewhere on the venter. In a few species the ducts are shorter and resemble those elsewhere, such as in P. thailandicus Williams. The function of this group of ducts on the frons is not known, but the area is probably in contact with the surface of the plant. We have not been able to observe these ducts in a few species, but occasionally our study has been limited to only one or two specimens for some species. A group of ducts on the frons is present in the type species of Ceroputo, C. pilosellae, and is also sometimes present in species of Phenacoccus although the ducts of the latter species are usually accompanied by setae.

Other features. The eyes on adult females of Puto are well developed, heavily sclerotised, and usually noticeably longer than wide and sometimes larger than the first-antennal segment. The circulus in Puto is usually much wider than long, sometimes constricted in the middle and occasionally split into two parts. Most dorsal setae are lanceolate with well-developed collars sometimes longer than wide, and often present in groups that form dorsal cerarii. Multilocular disc pores are present on the venter of the adult female of all species except $P$. peyerimhoffi (Vayssière) that possesses only quinquelocular pores. Of all species of Puto that we have studied, only P. peyerimhoffi has quinquelocular pores, which were illustrated by Marotta and Tranfaglia (1993). The absence of quinquelocular pores was given as a feature distinguishing Puto from Phenacoccus by Hardy et al. (2008), but $P$. peyerimhoffi clearly is an exception. The trilocular pores of the adult females of Puto species are larger on the dorsum and in the cerarii than on the venter. In some species, the trilocular pores in the cerarii are larger than trilocular pores on the rest of the derm and, in a few species, the venter has very few trilocular pores but many multilocular pores. Although the trilocular pores of Puto and of mealybugs are superficially similar, those of Puto have a slightly different appearance to the wax-exuding loculi.

Scanning electron micrographs (SEM) have been published of the trilocular pores of the Phenacoleachiidae (Phenacoleachia zealandica) (Cox 1984), the Putoidae (Puto superbus) (Cox 1984) and the Pseudococcidae (Ferrisia virgata (Cockerell) (Cox 1984) and Planococcus citri (Risso) (Foldi 1983)). Some differences in locular structure and wax filament form can be observed, but a more comprehensive SEM study would be informative.

\section{Taxonomy of Puto (Putoidae) and Ceroputo (Pseudococcidae) and transfer of some Puto species to Cero- puto}

The scored states of the diagnostic features of all species studied based on type specimens or other specimens are listed in Table 1. Included in Table 1 are also some species of Phenacoccus, and the type species of Ceroputo, $C$. pilosellae. Two species, Puto avitus (Menge) and P. trivenosus (Germar \& Berendt), are known only from descriptions of fossil insects, and we can offer no further information on them here. Puto brunitarsus (Signoret) cannot be discussed because original material is lost (Ben-Dov \& Matile-Ferrero, 1995). Puto konoi Takahashi is left in the genus Puto from its description only without seeing specimens, although it needs to be assessed to determine whether it belongs to Puto. Material of P. orthezioides (Cockerell) is represented by a third-instar female type specimen that has three sensilla on each surface of each trochanter, a pair of basal spurs on each claw, elongate oral collar ducts on the frons, numerous conical setae in the cerarii and a wide circulus. Based on these characteristics we conclude that it belongs in Puto. Species for which we suggest new or confirm previous taxonomic and nomenclatural changes, in this section and in Table 1, are: Puto asteri (Takahashi), P. erigeroneus (Kanda), P. graminis Danzig P. jarudensis Tang, P. mimicus McKenzie, P. nulliporus McKenzie, P. pini Danzig and P. vaccinii Danzig. We regard all the other species previously assigned to Puto to be included in the family Putoidae.

In Table 2, we list all species previously assigned to Puto together with their assignment based on our studies. As a result of our study, we recognise 47 extant and two fossil species of Puto and six species of Ceroputo. Below we provide revised synonymy lists and notes on the morphological features of species for which we either have additional information or suggest recombinations or include additional synonyms. We do not cite all the type data or type depositories, which are available in ScaleNet. For a few Puto species, we have additional data and these comments are provided in the section below on Puto. 
TABLE 2. List of species names formerly assigned* to Puto (left column) and their assignment in this paper (right column), excluding names previously regarded as synonyms. *As obtained from ScaleNet, accessed March to September 2010.

\begin{tabular}{|c|c|}
\hline Puto acirculus McKenzie & Puto acirculus McKenzie \\
\hline Puto albicans McKenzie & Puto albicans McKenzie \\
\hline Puto ambiguus (Fullaway) & Puto ambiguus (Fullaway) \\
\hline Puto antennatus (Signoret) & Puto antennatus (Signoret) \\
\hline Puto antioquensis (Murillo) & Pito antioquensis (Murillo) \\
\hline Puto arctostaphyli Ferris & Puto arctostaphyli Ferris \\
\hline Puto atriplicis McKenzie & Puto atriplicis McKenzie \\
\hline Puto avitus (Menge) & Puto avitus (Menge); a fossil species; identity unknown \\
\hline Puto barberi (Cockerell) & Puto barberi (Cockerell) \\
\hline Puto borealis (Borchsenius) & Puto borealis (Borchsenius) \\
\hline Puto brunnitarsus (Signoret) & Puto brunnitarsus (Signoret); original material lost; retained in Puto \\
\hline Puto bryanthi Ferris & Puto bryanthi Ferris \\
\hline Puto caballeroi (Gómez-Menor Ortega) & Puto caballeroi (Gómez-Menor Ortega) \\
\hline Puto calcitectus (Cockerell) & Puto calcitectus (Cockerell) \\
\hline Puto californicus McKenzie & Puto californicus McKenzie \\
\hline Puto caucasicus Hadzibejli & Puto caucasicus Hadzibejli \\
\hline Puto cupressi (Coleman) & Puto cupressi (Coleman) \\
\hline Puto decorosus McKenzie & Puto decorosus McKenzie \\
\hline Puto echinatus McKenzie & Puto echinatus McKenzie \\
\hline Puto erigeroneus (Kanda) & Recognised here as Ceroputo pilosellae Šulc, in agreement with Tang (1992) \\
\hline Puto graminis Danzig & Here transferred to Ceroputo as Ceroputo graminis (Danzig), comb. nov \\
\hline Puto israelensis Ben-Dov & Puto israelensis Ben-Dov \\
\hline Puto janetscheki Balachowsky & Puto janetscheki Balachowsky \\
\hline Puto jarudensis Tang & Regarded here as a junior synonym of Ceroputo pilosellae Šulc, syn. nov. \\
\hline Puto kondarensis (Borchsenius) & Puto kondarensis (Borchsenius) \\
\hline Puto konoi Takahashi & Puto konoi Takahashi \\
\hline Puto kosztarabi Miller \& Miller & Puto kosztarabi Miller \& Miller \\
\hline Puto lamottei Matile-Ferrero & Puto lamottei Matile-Ferrero \\
\hline Puto lasiorum (Cockerell) & Puto lasiorum (Cockerell) \\
\hline Puto laticribellum McKenzie & Puto laticribellum McKenzie \\
\hline Puto marsicanus Marotta \& Tranfaglia & Puto marsicanus Marotta \& Tranfaglia \\
\hline Puto megriensis (Borchsenius) & Puto megriensis (Borchsenius) \\
\hline Puto mexicanus (Cockerell) & Puto mexicanus (Cockerell) \\
\hline Puto mimicus McKenzie & Here transferred to Ceroputo as Ceroputo mimicus (McKenzie), comb. nov. \\
\hline Puto nulliporus McKenzie & Here transferred to Ceroputo as Ceroputo nulliporus (McKenzie), comb. nov. \\
\hline Puto orientalis Danzig & Puto orientalis Danzig \\
\hline Puto orthezioides (Cockerell) & $\begin{array}{l}\text { Puto orthezioides (Cockerell); described from immature specimens; retained in } \\
\text { Puto }\end{array}$ \\
\hline Puto pacificus McKenzie & Puto pacificus McKenzie \\
\hline Puto palinuri Marotta \& Tranfaglia & Puto palinuri Marotta \& Tranfaglia \\
\hline
\end{tabular}


TABLE 2. (continued)

\begin{tabular}{ll} 
Puto paramoensis Matile-Ferrero & Puto paramoensis Matile-Ferrero \\
Puto peyerimhoffi (Vayssière) & Puto peyerimhoffi (Vayssière) \\
Puto pilosellae (Šulc) & Ceroputo pilosellae Šulc \\
Puto pini Danzig & Recognised here as Ceroputo pini (Danzig), in agreement with Tang (1992) \\
Puto pricei McKenzie & Puto pricei McKenzie \\
Puto profusus McKenzie & Puto profusus McKenzie \\
Puto salinasi Foldi \& Kozár & Puto salinasi Foldi \& Kozár \\
Puto sandini Washburn & Puto sandini Washburn \\
Puto simmondsiae McKenzie & Puto simmondsiae McKenzie \\
Puto subericola (Vayssière) & Puto subericola (Vayssière) \\
Puto superbus (Leonardi) & Puto superbus (Leonardi) \\
Puto thailandicus Williams & Puto thailandicus Williams \\
Puto trivenosus (Germar \& Berendt) & Puto trivenosus (Germar \& Berendt); a fossil species; retained in Puto \\
Puto tubulifer Danzig & Puto tubulifer Danzig \\
Puto ulter Ferris & Puto ulter Ferris \\
Puto usingeri McKenzie & Puto usingeri McKenzie \\
Puto vaccinii Danzig & Recognised here as Ceroputo vaccinii (Danzig), in agreement with Tang (1992) \\
Puto yuccae (Coquillett) & Puto yuccae (Coquillett) \\
\hline
\end{tabular}

\section{PUTOIDAE}

\section{Puto Signoret}

Putonia Signoret, 1875: 341. Type species: Putonia antennata Signoret, by monotypy. Homonym of Putonia Stål, 1872, in Heteroptera.

Puto Signoret, 1876: 394. Replacement name for Putonia Signoret, 1875.

Macrocerococcus Leonardi, 1907: 151. Type species: Macrocerococcus superbus Leonardi, by original designation. Synonymy by Ferris, 1950.

The type species of Puto, now called P. antennatus (Signoret), was described by Signoret from female specimens collected on Pinus cembra (Pinaceae) at Briançon and male specimens from Abies pectinata (Pinaceae) at Chambéry, both from the French Alps (Reyne, 1954). Reyne (1954) produced a detailed redescription of most instars based on Signoret's type material plus additional specimens from France and Bavaria, and provided notes on the biology of the species. The adult males described by Reyne (1954) have 12 eyes on the head and the aedeagus is a curved rod with a rounded apex. The genus Macrocerococcus was erected for a species, now called $P$. superbus (Leonardi), described from Sardinia but now considered a polyphagous species distributed throughout much of the Palaearctic Region (Łagowska, 2000; Marotta \& Tranfaglia, 1993). Ferris (1950) treated the name Macrocerococcus as a junior synonym of Puto, and we agree with this synonymy. However, in agreement with Tang (1992) and Hardy et al. (2008), we reject the synonymy of Ceroputo with Puto, a taxonomic action attributable to Ferris (1918). We also reject Kawai's (1980) synonymy of Leococcus Kanda with Puto, as discussed below under the taxonomic notes on Ceroputo.

Diagnostic features. Adult female: eye height usually as great as length of first antennal segment; antennae usually with 9 segments, rarely with 8 ; antennal intersegmental sensilla present between segments III-IV, IV-V and VI-VII; each surface of trochanter with 2-5 (usually 3 or 4) campaniform sensilla; claw usually with pair of basal spurs; claw digitules often capitate but tarsal digitules almost never capitate; at least 18 pairs of cerarii on sclerotised plates, if more pairs present, increase due to division of cerarii on certain segments; long tubular ducts 
almost always present on frons (anterior to mouthparts); multilocular pores present on venter (except in P. peyerinhoffi); quinquelocular pores absent (except in P. peyerinhoffi); trilocular pores usually of 3 sizes, ventral pores smallest, dorsal pores noticeably larger, cerarian pores slightly larger than dorsal pores. Third-instar female: resembles adult female but with 8-segmented antennae, 2-3 campaniform sensilla on each surface of trochanter, fewer pores and ducts and a non-functional vulva. First-instar nymph: 7-segmented antennae; multilocular pores with $>5$ loculi. Adult male: row of 8-15 (usually 14) eyes surrounding head, plus a pair of lateral ocelli; with one pair of lateral filaments near apex of abdomen (each filament from glandular pouch on each side of abdominal segment VIII); penial sheath 1-segmented, apex of aedeagus either bifid or simple (Reyne, 1954; Beardsley, 1962; Miller \& Miller, 1993b; Hodgson \& Foldi, 2006).

\section{Puto caballeroi (Gomez-Menor)}

Douglasiella caballeroi Gómez-Menor Ortega, 1948: 114.

Puto caballeroi; Morrison, 1952: 75. Change of combination.

Macrocerococcus caballeroi; Kozár and Walter, 1985: 69. Change of combination.

Puto caballeroi; Ben-Dov, 1994: 420. Revived combination.

This species was described from Spain on pine. We examined seven adult females. We were able to examine 22 claws on the seven specimens and all seem to lack basal spurs, but they could be very small and difficult to see or damaged in the mounting procedure. The claw digitules are blunt. However the specimens have 3 campaniform sensilla on each surface of the trochanter, and intersegmental sensilla are present and distributed as in other species of Puto. We retain this species in Puto in agreement with Morrison (1952) and Ben-Dov (1994).

\section{Puto caucasicus Hadzibejli}

Puto caucasicus Hadzibejli, 1956: 515.

We examined the lectotype and two other adult females of this species, which were described from Abies species (Pinaceae) from southwestern Georgia. Ilya Gavrilov also examined other type specimens housed in the ZISP. The adult females have 8-segmented antennae with segment III about twice the length of the others and with pseudoarticulation, and each trochanter possesses two (rarely three) campaniform sensilla. The presence of spurs at the base of the claw and a well-developed claw denticle (Danzig, 1999, figure 4), as well as the distribution of intersegmental sensilla on the antennae of these specimens (Table 1), are features consistent with other species of Puto. Ilya Gavrilov also examined first-instar nymphs and stated that they have 6- or 7-segmented antennae and adult males have 5 pairs of unicorneal eyes.

\section{Puto janetscheki Balachowsky}

Puto janetscheki Balachowsky, 1953a: 295.

Puto alpinus Balachowsky, 1953a: 298. Synonymy by Marotta and Tranfaglia, 1993: 177.

Macrocerococcus janetscheki; Tang, 1992: 398. Change of combination.

This alpine Puto species was described from various plants in the Hautes Alpes of southeastern France. Puto alpi$n u s$ was described based on the third-instar female and was synonymised with $P$. janetscheki by Marotta and Tranfaglia (1993). The claws are without denticles, but other features of the adult female are typical for Puto species, including the presence of a pair of basal spurs on each claw. We agree with the illustration of this species given by Marotta and Tranfaglia (1993) but we provide additional information on the antennal sensilla in Table 1. 


\section{Puto peyerimhoffi (Vayssière)}

Phenacoccus peyerimhoffi Vayssière, 1923: 152-155.

Puto peyerimhoffi; Balachowsky, 1953b: 304. Change of combination.

Vayssière (1923) described the adult female, adult male and first-instar nymph of this species from the Aurès mountains of Algeria on Juniperus thurifera (Cupressaceae). The generic and family placement of this species is problematic because it possesses characteristics of both Puto and Ceroputo as understood here. The presence of 12 eyes on the adult male, seven-segmented antennae on the first-instar nymph and, on the adult female, basal spurs on the claw, tubular ducts on the frons, and three sensilla on each surface of the trochanter, are features consistent with species of Puto. The absence of multilocular pores and the presence of quinquelocular pores are features consistent with species of Ceroputo. The similarity of this species to Ceroputo nulliporus and C. mimicus was pointed out by Marotta and Tranfaglia (1993). We here retain this species in Puto because it possesses more features of this genus than of Ceroputo, but further investigations are required. We agree with the illustration of this species given by Marotta and Tranfaglia (1993) but provide corrected information on the tubular duct distribution and number of sensilla on the trochanter in Table 1.

\section{Puto salinasi Foldi and Kozár}

Puto salinasi Foldi and Kozar, 2006: 309.

This species, collected from high elevation in Venezuela on Espeletia timotensis (Asteraceae), has tubular ducts in the cerarii. The ducts were described originally as wide, but the illustration shows them with rims. We have not been able to detect the rims in the type specimens.

\section{Puto subericola (Vayssière)}

Phenacoccus subericola Vayssière, 1927: 110.

Puto subericola; Balachowsky, 1953b: 304. Change of combination.

The type specimens were collected on Quercus suber (Fagaceae) in Morocco. We studied the lectotype, two paralectotypes and 11 other specimens from Morocco. Of the six claws present on the lectotype, only one claw has basal spurs. There are nine claws only on eight paralectotypes and we have not been able to detect any basal spurs. Three other specimens are available from Morocco, collected on Vitis vinifera; on one specimen with five claws, only two claws possess basal spurs, another specimen with one claw has basal spurs and the other specimen has two claws, both have basal spurs. We presume that spurs are normally present on all claws and that damage to the legs has occurred during handling of the specimens or by chemical treatment during slide preparation.

\section{Puto superbus (Leonardi)}

Macrocerococcus superbus Leonardi, 1907: 152.

Ceroputo volynicus Nasonov, 1908: 472. Synonymy by Borchsenius, 1949: 296.

Ceroputo superbus; Lindinger, 1912: 65. Change of combination.

Phenacoccus seurati Vayssière, 1927: 109. Synonymy by Balachowsky, 1953b: 304.

Macrocerococcus tauricus Borchsenius, 1948: 33. Synonymy by Danzig, 1999: 84.

Macrocerococcus kiritshenkoi Borchsenius, 1949: 298. Synonymy by Danzig, 1999: 84.

Puto tauricus; Tereznikova, 1975a: 240. Change of combination.

Puto superbus; Tereznikova, 1975a: 241. Change of combination.

Macrocerococcus kiritzhenkoi; Tang, 1992: 398. Misspelling of species name.

Puto kiritshenkoi; Ben-Dov, 1994: 424. Change of combination. 
Puto superbus was described from Tempio, Sardinia, Italy, on unidentified species of grass (Poaceae) in 1907 by G. Leonardi. We have examined specimens from the type series that have identical data as the lectotype and also were mounted from dried specimens included in Chermotheca Italica (Leonardi, 1909). We agree with the illustration of this species given by Marotta and Tranfaglia (1993). We also have examined a wingless adult male from Fürth, Germany, on grass and it possesses eight eyes in addition to the lateral ocelli and one pair of lateral filaments. There is a possibility that $P$. superbus encompasses more than one species. Marotta and Tranfaglia (1985) discussed the variation in the dorsal tubular ducts in the cerarii but later (Marotta \& Tranfaglia, 1993) determined that $P$. superbus lacked dorsal ducts entirely. Specimens with these ducts were identified as $P$. tauricus. Danzig (1999) again placed $P$. tauricus as a junior subjective synonym of $P$. superbus. A careful analysis of all species in the genus is required to sort out their true identity. For this paper we have studied types of the junior synonyms Puto kiritshenkoi (Borchsenius), Puto tauricus (Borchsenius) and Phenacoccus seurati Vayssière but had insufficient series of specimens to come to definitive conclusions about synonyms.

\section{Puto thailandicus Williams}

Puto thailandicus Williams, 2004: 711.

This is the only species of Puto known from the tropical areas of southern Asia, all other members of the genus occur in the Palaearctic, Nearctic and Neotropical Regions. It was collected at 2400 metres in humid forest in Thailand. The tubular ducts on the frons of $P$. thailandicus are about the same size as the other ventral ducts, which is a distinctive feature of the species.

\section{Puto tubulifer Danzig}

Puto tubulifer Danzig, 1978: 125.

Ceroputo tubulifer; Tang, 1992: 392. Change of combination.

Puto tubulifer; Ben-Dov, 1994: 431. Revived combination.

We examined two paratypes and another adult female of this Russian species and all possess large dorsal tubular ducts among the cerarii. Similar ducts extend over much of the head and thorax but on the abdomen they are present around the margins only. Tang (1992) transferred this species to Ceroputo but the morphological characteristics fit those of Puto.

\section{PSEUDOCOCCIDAE}

\section{Ceroputo Šulc}

Ceroputo Šulc, 1898: 1. Type species: Ceroputo pilosellae Šulc, by original designation.

Leococcus Kanda, 1959: 239. Type species: Leococcus erigeroneus Kanda, by monotypy and original designation. Synonymy by Tang, 1992: 388.

Ceroputo was synonymised with Puto by Ferris (1918) [not by Danzig 1980, as suggested by Ben-Dov 1994 and ScaleNet], but treated as a valid genus by Tang (1992). Hardy et al. (2008) treated Ceroputo as a genus of the mealybug subfamily Phenacoccinae, which they redefined. We concur with Tang (1992) and Hardy et al. (2008). The molecular phylogenetic studies by M. Bora Kaydan (pers. comm.) also have confirmed the placement of $C$. pilosellae in the Pseudococcidae near some species of Phenacoccus. Here we diagnose Ceroputo based largely on the adult female and transfer several species to it from Puto. Afifi (1968) described the adult male of C. pilosellae (based on specimens from Fragaria vesca from Belgrade, in the former Yugoslavia now Serbia) as having a pair of dorsal and a pair of ventral simple eyes and a pair of lateral ocelli. It also has two pairs of lateral filaments on the abdomen, features that are consistent with this species being a true pseudococcid. We also recognise Leococcus 
Kanda as a junior synonym of Ceroputo, in agreement with Tang (1992). Previously Leococcus was treated as a junior synonym of Puto, a synonymy suggested by Kawai (1980). Kanda (1959) stated how his genus Leococcus differed from Puto and Ceroputo but the features that he listed are all shared with the type species of Ceroputo. We recognise a total of six species in Ceroputo and discuss each of these species following the generic diagnosis.

Diagnosis features. Adult female: eye height as great as or greater than length of first antennal segment (usually very much smaller in typical Phenacoccus, except $P h$. solenopsis); antennae with 8-9 segments; 0-2 (usually 0 ) antennal intersegmental sensilla present between each of segments III-IV, IV-V and VI-VII; 2 campaniform sensilla on each surface of each trochanter; claw lacking basal spurs; claw digitules capitate but tarsal digitules either capitate or not; more than 17 pairs of cerarii on sclerotised plates; long tubular ducts present or absent on frons (anterior to mouthparts); trilocular pores on venter usually smaller than those on dorsum, and pores in cerarii at most only slightly larger than those on rest of dorsum; quinquelocular pores sometimes present. First-instar nymph: 6-segmented antennae; multilocular pores with $>5$ loculi absent. Adult male of $C$. pilosellae (adult males unknown in other species): head with one pair of dorsal and one pair of ventral simple eyes plus a pair of lateral ocelli; with 2 pairs of lateral filaments on posterior abdominal segments (each filament from glandular pouch on each side of abdominal segments VII and VIII); penial sheath 1-segmented, apex of aedeagus simple (Afifi, 1968).

\section{Ceroputo graminis (Danzig) comb. nov.}

Puto graminis Danzig, 1972b: 335.

Adult female type specimens have been available for study. The eyes are approximately the same height as the length of the first antennal segment. There are two campaniform sensilla on each surface of each trochanter except on the surface of one trochanter which apparently has three. There is a very small denticle and no basal spurs on the claws. The trilocular pores occur in two sizes: the dorsal pores are larger than those on venter. Danzig $(1980,1999)$ reports that the adult female lacks both quinquelocular and multilocular pores. We consider this species to best fit into Ceroputo based on the two sensilla on each trochanter surface, lack of basal spurs, and lack of multilocular pores (a character state shared with C. nulliporus).

\section{Ceroputo mimicus (McKenzie) comb. nov.}

Puto mimicus McKenzie, 1967: 352.

The original collection of this species was on Encelia frutescens (Asteraceae) in Imperial County and on Petalonyx thurberi (Loasaceae) from Riverside County, both in California, U.S.A. We also have seen specimens in the USNM from Travertine Rock, Imperial County, California, on Hymenoclea salsola (Asteraceae), and from Thermal, Riverside County, California, on Ambrosia psilostachya (Asteraceae). Williams and Granara de Willink (1992) commented on this species and decided that it might not belong to the genus Puto. Character states that seem to exclude this species from Puto are: the campaniform sensilla on the trochanters are always two in number on each surface, the antennal intersegmental sensilla are tiny and present only between segments VI and VII, the tubular ducts on the frons are absent, and quinquelocular pores are present on the venter. Character states that it shares with species of Puto are the possession of a pair of minute basal spurs on each claw. Despite some conflicting evidence, we conclude that this species does not belong to Puto and transfer it to Ceroputo.

\section{Ceroputo nulliporus (McKenzie) comb. nov.}

Puto nulliporus McKenzie, 1960: 733.

This species is known only from the original collection on Bebbia juncea var. aspera (Asteraceae) from near Palo Verde, and on Encelia farinosa (Asteraceae) from Glamis, both in Imperial County, California, U.S.A. The placement of this species was regarded as doubtful by Williams and Granara de Willink (1992). Character states that 
exclude this species from Puto are the campaniform sensilla on the trochanters are always two in number on each surface, the antennal intersegmental sensilla are tiny and present only between segments VI and VII, there are no multilocular pores, and the trilocular pores in the cerarii are the same size as those on the rest of the derm. Character states that it shares with species of Puto are the possession of basal spurs on the claw, although the spurs on $C$. nulliporus are thin and very poorly developed. Despite some conflicting evidence, we conclude that this species does not belong to Puto and transfer it to Ceroputo.

\section{Ceroputo pilosellae Šulc}

Ceroputo pilosellae Šulc, 1898: 2.

Ceroputo elvirae castneri Schumacher, 1917: 429. Nomen nudum; discovered by Lindinger, 1935: 131.

Phenacoccus tomlini Green, 1930: 320. Synonymy by Marotta and Tranfaglia, 1993: 188.

Phenacoccus asteri Takahashi, 1932: 43. Syn. nov.

Erium tomlini; Lindinger, 1935: 122. Change of combination.

Phenacoccus ferrisi Kiritshenko, 1936: 140. Synonymy by Danzig, 1999: 89.

Phenacoccus euphorbiaefolius Bodenheimer, 1943: 17. Synonymy by Ben-Dov and Kaydan, 2008: 285.

Phenacoccus poterii Bodenheimer, 1943: 32. Synonymy by Ben-Dov and Kaydan, 2008: 285.

Ceroputo ferrisi; Borchsenius, 1949: 287. Change of combination.

Ceroputo pannosus Borchsenius, 1949: 288. Synonymy by Tereznikova, 1975b: 32.

Ceroputo clematidis Matesova, 1957: 165. Synonymy by Danzig, 1999: 89.

Leococcus erigeroneus Kanda, 1959: 240. Synonymy by Tang, 1992: 388, 391.

Puto pilosellae; Tereznikova, 1975a: 243. Change of combination.

Puto erigeroneus; Kawai, 1980: 96. Change of combination.

Puto clematidis; Kozár and Walter, 1985: 72. Change of combination.

Puto euphorbiaefolius; Kozár and Walter, 1985: 72. Change of combination.

Puto ferrisi; Kozár and Walter, 1985: 72. Change of combination.

Puto poterii; Kozár and Walter, 1985: 72. Change of combination.

Puto asteri; Tang, 1992: 405. Change of combination.

Phenacoccus asteri; Ben-Dov, 1994: 309. Revived combination.

Puto jarudensis Tang, 1992: 600. Syn. nov.

We examined 13 adult females identified as C. pilosellae that were collected in "Czechoslovakia," France, Hungary, Poland and Slovakia. We also have examined a slide with an adult female intercepted at New York from England on Gentiana andrewsii collected May 12, 1936, by Lennox but, because this species has never been collected in the UK, the locality data are suspect. In this species, the eyes are about the same height as the length of first antennal segment. We have examined specimens with 8- and 9-segmented antennae. The intersegmental sensilla are variable and often obscure and difficult to see. It appears that they are variably present between segments IIIIV, IV-V and VI-VII. One specimen appears to have sensilla between the above mentioned segments as well as VVI and VIII-IX. The legs are shorter than those in Puto and possess fewer setae; campaniform sensilla on the trochanters always number two on each surface; the claws are thick and short and lack basal spurs, and the digitules are clubbed. Tubular ducts are present on the frons. Trilocular pores on the venter are smaller than those on the dorsum, and pores in the cerarii are only slightly larger than those on the rest of the dorsum.

First-instar nymphs collected in Hungary (Budapest, Sashegy, 18.x.1996, in caricetum habitat by B. Kiss) and examined by Ferenc Kozár, and embryos collected in Turkey (Hakkari-Beyköy, on Euphorbia sequeriana (Euphorbiaceae), $1832 \mathrm{~m}$ ) and examined by M. Bora Kaydan, all possess 6 antennal segments. We agree with Hardy et al. (2008) that this species should be retained in the genus Ceroputo in the family Pseudococcidae. This species has a wide distribution in the Palaearctic Region (Ben-Dov \& Kaydan, 2008).

Kanda (1959) described Leococcus erigeroneus, collected from Erigeron canadensis (Asteraceae) in Japan, as the type species of his genus Leococcus. Kawai (1980) transferred the species to Puto, thus treating Leococcus as a junior synonym of Puto. Danzig (1980) suggested that L. erigeroneus was probably a synonym of $P$. pilosellae but did not formally list it as such. Tang (1992) appears to have been the first to formally cite L. erigeroneus as a junior synonym of $C$. pilosellae. We have studied the description and illustration given by Kanda (1959) and we conclude that the species is identical to C. pilosellae.

Takahashi (1932) described Phenacoccus asteri for specimens collected on Aster lauruleanus (Asteraceae) in Taiwan. It was transferred to Puto by Tang (1992), but the original combination was revived by Ben-Dov (1994). 
We have examined the original illustration and description of this species and regard the species name to be identical to $C$. pilosellae, with which we here synonymise it.

We have not studied specimens of Puto jarudensis Tang described from China on Kalimeris integrifolia (Asteraceae). The description and illustration given by Tang (1992), however, leaves little doubt that the species is identical to C. pilosellae. Tang (1992) points out that $P$. jarudensis has two sizes of tubular ducts, with larger ones mainly in the ventral median areas of the head and thorax, and smaller ones on the ventral abdomen. Although existing descriptions of C. pilosellae (Danzig, 1980; Kosztarab \& Kozár, 1988; Marotta \& Tranfaglia, 1993) do not provide details of the size of the ventral ducts, the specimens of $C$. pilosellae from Europe that we have examined have larger tubular ducts on the head and thorax than those on the abdomen, in agreement with Tang's description of $P$. jarudensis.

\section{Ceroputo pini (Danzig) comb. rev.}

Puto pini Danzig, 1972a: 270.

Ceroputo pini; Tang, 1992: 392. Change of combination.

Puto pini; Ben-Dov, 1994: 429. Revived combination.

Three adult female type specimens have been available for study. We have found only one antennal intersegmental sensillum between segments IV and V in one antenna. However, the antennal segments were mounted in such a way that the intersegmental membranes were not visible. Eye height is greater than the length of the first antennal segment. The legs always possess only two campaniform sensilla on each surface of each trochanter, basal spurs are absent from the claws, each claw has a well-developed denticle, and the claw and tarsal digitules are only slightly clubbed. The 18 main cerarii are on well-sclerotised plates, whereas the sclerotisation of the supplementary cerarii varies among cerarii and specimens. The cerarian setae are more slender than those in $C$. pilosellae. There are tubular ducts on the dorsum and there are two sizes of trilocular pores on the derm, with the dorsal pores larger than the ventral pores. Dorsal oral collar tubular ducts are present, each slightly larger than those on the venter. As shown by Danzig (1980), this species possesses ventral multilocular disc pores on the posterior abdominal segments and there are a few quinquelocular pores near the labium. We conclude that the species does not belong to Puto but to Ceroputo to which Tang (1992) transferred it.

\section{Ceroputo vaccinii (Danzig) comb. rev.}

Puto vaccinii Danzig, 1978: 125.

Ceroputo vaccinii; Tang, 1992: 393. Change of combination.

Puto vaccinii; Ben-Dov, 1994: 432. Revived combination.

We examined two paratypes and another three adult females, all from Russia on Vaccinium. On the nine antennae examined, we could find only a single intersegmental sensillum between segments III and IV on one antenna. Between segments IV-V there is also a single sensillum on one antenna. Between segments VI and VII there are no sensilla on two antennae, one sensillum on six antennae and two sensilla on one antenna. The eyes are slightly smaller than the length of the first antennal segment. There are two campaniform sensilla on each surface of each trochanter and basal spurs are absent from all claws. The cerarii are on sclerotised plates with each of the anal lobe cerarii possessing 6-8 lanceolate setae. Other cerarii each have 4-6 setae but occasionally one or two cerarii may have only two setae. Tubular ducts are present on the frons but not in a group as in Puto. Disc pores, each with 5-8 loculi, are present on the venter but are absent from the head and thorax; pores with 5 loculi are located only around the vulva. There are two sizes of trilocular pores, with dorsal pores larger than ventral pores.

This species is similar to C. pilosellae but differs mainly in lacking disc pores on the head and thorax. We agree with Tang (1992) that its correct placement is in Ceroputo. Ben-Dov (1994) listed this species under Puto, although he was aware of the recombination by Tang (1992), presumably because he had doubt as to its generic placement. 


\section{Phenacoccus Cockerell}

We have examined several species of Phenacoccus (listed in Table 1) including the type species, Ph. aceris, with particular emphasis on those species with more than two setae in the cerarii.

Diagnosis of adult female. Eye height usually shorter than first antennal segment; antennae usually with 8 or 9 segments, but sometimes with as few as 6; 0-2 antennal intersegmental sensilla present between segments VIVII, absent between segments III-IV, IV-V; 2 campaniform sensilla on each surface of each trochanter; claw lacking basal spurs; claw digitules capitate but tarsal digitules simple; 18 or fewer pairs of cerarii; tubular ducts usually absent on frons; trilocular pores on venter smaller than those on dorsum, dorsal and cerarian pores approximately equal in size; quinquelocular pores usually present. First-instar nymph: 6-segmented antennae; multilocular pores with $>5$ loculi absent. Adult male: head with one pair of dorsal and one pair of ventral simple eyes plus lateral ocelli; 2 pairs of lateral filaments on posterior abdominal segments (each filament from glandular pouch on each side of abdominal segments VII and VIII); penial sheath apparently 2-segmented, apex of aedeagus simple and slightly rounded or pointed (Beardsley 1960, 1962; Miller \& Appleby, 1971; Hardy et al. 2008; Hodgson et al., 2008).

\section{Concluding remarks}

In several instances we mention the possibility of cryptic species. Puto superbus in the Old World and P. yuccae (Coquillett) in the New World are examples of species that show a wide range of morphological variation. Careful analysis of current species concepts in the context of monographic studies using molecular and morphological analysis would be highly beneficial. It is possible that future phylogenetic analyses may help to recognise taxonomic groupings within Puto. There is much variation in morphology among species from different regions and from conifer versus non-conifer host plants, but the taxonomic significance of this morphological diversity has not been investigated thoroughly. Given that fossils of Putoidae were present perhaps as early as 135 mya (Koteja \& Azar, 2008), it is not surprising that Puto shows morphological diversity.

The late Salvatore Marotta published four important papers on Puto (Marotta \& Tranfaglia, 1985, 1993, 1995; Marotta 1992) and had planned further detailed studies of the genus. We dedicate this paper to his memory.

\section{Acknowledgements}

We are most grateful to Evelyna Danzig and Ilya Gavrilov, Zoological Institute, St Petersburg, Russia, for allowing us to study many of the species from Russia and neighbouring countries. Ilya Gavrilov also helped in sending us character details of some of the Palaearctic species, which we acknowledge with gratitude. We thank Ferenc Kozár for examining first-instar nymphs of Ceroputo pilosellae, and M. Bora Kaydan, Yuzimcu University, Van, Turkey, for examining embryos of $C$. pilosellae in specimens from Turkey. In addition, M. Bora Kaydan and Ferenc Kozár kindly examined the paratype of Puto salinasi deposited in the Plant Protection Institute, Hungarian Academy of Sciences, Budapest, Hungary, and Bora made available his unpublished molecular phylogenetic data on C. pilosellae and Phenacoccus. We are most thankful to Ting-kui Qin, Plant Biosecurity (Horticulture), Department of Agriculture, Canberra, Australia, for translating the Chinese description of Puto jarudensis into English. We are grateful to Haley Bastien for assisting with adding and checking references, and to Takumasa Kondo for edits to the figure. We thank Ray Gill, California Department of Food and Agriculture, Sacramento, USA, and Ronald Ochoa and Gary Miller, Systematic Entomology Laboratory, Agricultural Research Service, US Department of Agriculture, Beltsville, Maryland, USA, for reviewing the manuscript and providing useful comments. We also extend our thanks to Chris Hodgson for his useful comments and suggestions about the layout of the text, which have greatly improved the manuscript. This work was supported in part by Hatch funding from the California Agricultural Experiment Station to PJG. 


\section{References}

Afifi, S.A. (1968) Morphology and taxonomy of the adult males of Pseudococcidae and Eriococcidae (Homoptera : Coccoidea). Bulletin of the British Museum (Natural History) Entomology, Supplement, 13, 1-210.

Balachowsky, A.S. (1953a) Sur deux Pseudococcini Hom. (Coccoidea) nouveaux appartenant à la faune alpine d'altitude. Mitteilungen der Sweizerischen Entomologischen Gesellschaft, 26, 295-300.

Balachowsky, A.S. (1953b) Sur le statut des genres Puto Signoret, Ceroputo Sulc. et Macrocerococcus Leonardi. Mitteilungen der Sweizerischen Entomologischen Gesellschaft, 26, 301-304.

Beardsley, J.W. (1960) A preliminary study of the males of some Hawaiian mealybugs (Homoptera: Pseudococcidae). Proceedings of the Hawaiian Entomological Society, (1959), 17, 199-243.

Beardsley, J.W. (1962) Descriptions and notes on male mealybugs (Homoptera: Pseudococcidae). Proceedings of the Hawaiian Entomological Society, 28, 81-98.

Beardsley, J.W. (1962) Descriptions and notes on male mealybugs (Homoptera: Coccoidea). Proceedings of the Hawaiian Entomological Society, 18, 81-98.

Beardsley, J.W. (1969) A new fossil scale insect (Homoptera: Coccoidea) from Canadian amber. Psyche, 76, $270-279$.

Ben-Dov, Y. (1994) A Systematic Catalogue of the Mealybugs of the World (Insecta: Homoptera: Coccoidea: Pseudococcidae and Putoidae) with Data on Geographical Distribution, Host Plants, Biology and Economic Importance. Intercept Ltd, Andover, U.K., 686 pp.

Ben-Dov, Y. \& Kaydan, M.B. (2008) Puto pilosellae (Šulc), new synonymy and distribution records (Hem. Coccoidea, Putoidae). Bulletin de la Société entomologiue de France, 113, 285-286.

Ben-Dov, Y. \& Matile-Ferrero, D. (1995) The identity of the mealybug taxa described by V.A. Signoret (Homoptera, Coccoidea, Pseudococcidae). Bulletin de la Société entomologique de France, 100, 241-256.

Ben-Dov, Y., Miller, D.R. \& Gibson, G.A.P. (2010) ScaleNet. http://www.sel.barc.usda/scalenet/scalenet.htm (Last accessed 12 December 2010)

Bodenheimer, F.S. (1943) A first survey of the Coccoidea of Iraq. Government of Iraq, Ministry of Economics, Directorate General of Agriculture, Bulletin, 28, 1-33.

Borchsenius, N.S. (1948) [Review of Palaearctic soft scales of the genus Macrocerococcus Leon. (Coccoidea, Pseudococcidae).] (in Russian) Entomologicheskoe Obozrenye, 30, 31-39.

Borchsenius, N.S. (1949) [Insects Homoptera. suborders mealybugs and scales (Coccoidea). Family mealybugs (Pseudococcidae). Vol. VII.] (in Russian) Fauna SSSR. Zoologicheskii Institut Akademii Nauk SSSR. N.S., 38, 1-382.

Borchsenius, N.S. (1958) [On the evolution and phylogenetic interrelations of Coccoidea (Insecta, Homoptera).] (in Russian with English summary) Zoologicheskiu Zhurnal, 37, 765-780.

Cook, L.G., Gullan, P.J. \& Trueman, H.E. (2002) A preliminary phylogeny of the scale insects (Hemiptera: Sternorrhyncha: Coccoidea) based on nuclear small-subunit ribosomal DNA. Molecular Phylogenetics and Evolution, 25, 43-52.

Cox, J.M. (1984) Relationships of the Phenacoleachiidae (Homoptera: Coccoidea). Proceedings of the 10th International Symposium of Central European Entomofaunistics, Budapest, 15-20 August 1983, 339-341.

Danzig, E.M. (1972a) [New and little-known species of the scale insects (Homoptera, Coccoidea) from Siberia and the far east of the USSR.] (in Russian) Trudy Zoologicheskogo Instituta, Leningrad, 52, 261-276.

Danzig, E.M. (1972b) [Contribution to the fauna of the white flies and scale insects (Homoptera: Aleyrodoidea, Coccoidea) of Mongolia.] (in Russian) Insects of Mongolia, 1, 325-348.

Danzig, E.M. (1978) [New species of mealybugs (Homoptera, Coccoidea) from Siberia and the Far East. In: New Species of Animals.] (in Russian) Trudy Akademii Nauk SSR Zoologicheskogo Instituta. 61, 124-132.

Danzig, E.M. (1980) Scale insects of the Far East of the USSR (Homoptera, Coccinea) SSSR [Keys to the fauna of the USSR]. (in Russian) Nauka, Leningrad, 368 pp.

Danzig, E.M. (1999) [Mealybugs of the genus Puto Signoret (Homoptera, Pseudococcidae) from Russia and adjacent countries.] (in Russian) Entomologicheskoye Obozrenie, 78, 79-91.

De Lotto, G. (1964) Observations on African mealy bugs (Hemiptera: Coccoidea). Bulletin of the British Museum (Natural History) Entomology, 14, 343-397.

De Lotto, G. (1979) On two podal features in the mealybugs (Homoptera: Pseudococcidae). Journal of the Entomological Society of Southern Africa, 42, 11-15.

Ferris, G.F. (1918) The California species of mealy bugs. Leland Stanford Junior University Publications, University Series, Palo Alto, 78 pp.

Ferris, G.F. (1950) Atlas of the Scale Insects of North America. Series V. The Pseudococcidae (Part 1). Palo Alto, California, Stanford University Press, 278 pp.

Foldi, I. (1983) Structure et fonctions des glandes tégumentaires de cochenilles Pseudococcines et de leurs secretions. Annales de la Société entomologique de France, 19, 155-156.

Foldi, I. \& Kozár, F. (2006) New species of Cataenococcus and Puto from Brazil and Venezuela, with data on others species (Hemiptera, Coccoidea). Nouvelle Revue d'Entomologie, 22, 305-312.

Giliomee, J.H. (1961) Morphological and taxonomic studies on the males of three species of Pseudococcus (Hemiptera: Coccoidea). Annale Universittett van Stellenbosch (Serie A), 36, 239-296. 
Giliomee, J.H. (1967) Morphology and taxonomy of adult males of the family Coccidae (Homoptera: Coccoidea). Bulletin of the British Museum (Natural History) Entomology, Supplement, 7, 1-168.

Gómez-Menor Ortega, J. (1948) Adiciones a los "Cóccidos de España" (2a nota). EOS - Revista Espanola de Entomologia, 24, $73-121$.

Green, E.E. (1930) A new species of Phenacoccus (Coccidae) from the eastern Alps. Annals and Magazine of Natural History, $5,320-322$.

Gullan, P.J. \& Cook, L.G. (2002) Phenacoleachia Cockerell (Hemiptera: Coccoidea: Phenacoleachiidae). Bollettino di Zoologia agraria e Bachicoltura, 33, 163-173.

Gullan, P.J. \& Cook, L.G. (2007) Phylogeny and higher classification of the scale insects (Hemiptera: Sternorrhyncha: Coccoidea). Zootaxa, 1668, 413-425.

Hadzibejli, Z.K. (1956) A new species of the genus Puto Sign. (Homoptera, Coccoidea) from the mountain zone of Georgia. Soobshchenya Akademii Nauk Gruzinskoy SSR, 17, 515-518.

Hardy, N.B., Gullan, P.J. \& Hodgson, C.J. (2008) A classification of mealybugs (Hemiptera: Coccoidea) based on integrated molecular and morphological data. Systematic Entomology, 33, 51-71.

Hodgson, C.J. (2002) Preliminary phylogeny of some non-margarodid Coccoidea (Hemiptera) based on adult male characters. Bollettino di Zoologia agraria e Bachicolura, Serie II, 33, 129-137.

Hodgson, C.J., Abbas, G., Arif, M.J., Saeed, S. \& Karar, H. (2008) Phenacoccus solenopsis Tinsley (Sternorrhyncha: Coccoidea: Pseudococcidae), an invasive mealybug damaging cotton in Pakistan and India, with a discussion on seasonal morphological variation. Zootaxa, 1913, 1-35.

Hodgson, C.J. \& Foldi, I. (2005) Preliminary phylogenetic analysis of the Margarodidae sensu Morrison and related taxa (Hemiptera: Coccoidea) based on adult male morphology. Proceedings of the X International Symposium of Scale Insect Studies held at Adana, Turkey, 19-23 April, 2004, pp. 35-47.

Hodgson, C.J. \& Foldi, I. (2006) A review of the Margarodidae sensu Morrison (Hemiptera: Coccoidea) and some related taxa based on the morphology of adult males. Zootaxa, 1263, 1-250.

Hodgson, C.J. \& Henderson, R.C. (2004) Coccidae (Insecta: Hemiptera: Coccoidea): adult males, pupae and prepupae of indigenous species. Fauna of New Zealand, 51, 1-229.

Hughes-Schrader, S. (1944) A primitive coccid chromosome cycle in Puto sp. Biological Bulletin, 87, 167-176.

Hughes-Schrader, S. (1948) Cytology of coccids (Coccoidea-Homoptera). Advances in Genetics, 2, 127-203.

Kanda, S. (1959) Two new genera and two new species of the Pseudococcidae (Homoptera). Kontyu, 27, $239-243$.

Kawai, S. (1980) Scale Insects of Japan in Colors. Tokyo, Japan, National Agricultural Education Association, 455 pp.

Kiritshenko, A.N. (1936) [Some new Pseudococcinae of the fauna of USSR (Hemiptera, Coccoidea).] (in Russian) Entomologicheskoye Obozrenie (1935) 26, 130-59.

Kosztarab, M. \& Kozár, F. (1988) Scale Insects of Central Europe. Akademiai Kiado, Budapest. 456 pp.

Koteja, J. (1974a) Comparative studies on the labium in the Coccinea (Homoptera). Zeszyty Naukowe Akademii Rolniczej w Krakowie, 27, 1-162.

Koteja, J. (1974b) On the phylogeny and classification of the scale insects (Homoptera, Coccinea) (discussion based on the morphology of the mouthparts). Acta Zoologica Cracoviensia, 19, 267-326.

Koteja, J. (1974c) The occurrence of a campaniform sensillum on the tarsus in the Coccinea (Homoptera). Polskie Pismo Entomologiczne, 44, 243-252.

Koteja, J. (1980) Campaniform, basiconic, and intersegmental sensilla on the antennae in the Coccinea (Homoptera). Acta Biologica Cracoviensia, Series Zoologica, 22, 73-88.

Koteja, J. (1996) Scale Insects (Homoptera: Coccinea) a Day After. In: Schaefer, C.W. (Ed.), Studies on Hemipteran Phylogeny. Thomas Say Publications in Entomology, Proceedings. Entomological Society of America, Lanham, Maryland, pp. 65-88.

Koteja, J. (2000) Scale insects (Homoptera, Coccinea) from Upper Cretaceous New Jersey amber, In: Grimaldi, D. (Ed.), Studies on Fossils in Amber with particular reference to Cretaceous of New Jersey, Backhys Publishers, Leiden, The Netherlands, viii, pp. 147-229.

Koteja, J. \& Azar, D. (2008) Scale insects from Lower Cretaceous amber. Alavesia, 2, 133-167.

Koteja, J. \& Poinar, G.O. (2001) A new family, genus, and species of scale insect (Hemiptera: Coccoidea: Kukaspididae, new family) from Cretaceous Alaskan amber. Proceedings of the Entomological Society of Washington, 103, 356-363.

Koteja, J. \& Zak-Ogaza, B. (1972) Morphology and taxonomy of the male Kermes quercus (L.) (Homoptera, Coccoidea). Acta Zoologica Cracoviensia, 17, 193-215.

Kozár, F. \& Walter, J. (1985) Check-list of the Palaearctic Coccoidea (Homoptera). Folia Entomologica Hungarica, 46, 63110.

Łagowska, B. (2000) Puto superbus (Leonardi, 1907) (Homoptera: Pseudococcidae) new to the Polish fauna. Polskie Pismo Entomologiczne, 69, 3-6.

Leonardi, G. (1907) Contribuzione alla conoscenza delle cocciniglie Italiane. Bollettino del Laboratorio del Zoologia generale e agraria, 1, 135-169.

Leonardi, G. (1909) Chermotheca Italica Continens Exsiccata, In Situ, Coccidarum Plantis Precipue Cultis, In Italia Occurrentibus Obnoxiarum. Cocciniglie Raccolte in Italia. Vesuviano, Portici, Fascicolo V, (106) 125 pp.

Lindinger, L. (1912) Die Schildläuse (Coccidae) Europas, Nordafrikas und Vorder-Asiens, einschliesslich der Azoren, der Kanaren und Madeiras. Ulmer, Stuttgart. 388 pp. 
Lindinger, L. (1935) Neue Beiträge zur Kenntnis der Schildläuse (Coccidae). Entomologische Zeitschrift, 49, 121-123.

Malumphy, C. (2010) Barber giant mealybug Puto barberi (Cockerell) (Hemiptera: Pseudococcidae), a Neotropical pest of ornamental plants established in Gran Canaria, Spain. Entomologist's Monthly Magazine, 146, 21-25.

Marotta, S. (1992) Osservazioni bio-etologiche su Puto superbus (Leonardi) (Homoptera Coccoidea Pseudoccidae) su Arrhenatherum elatius Mert. E. K. in Aruzzo. Redia, 75, 485-499.

Marotta, S. \& Tranfaglia, A. (1985) Ridescrizione di Macrocerococcus superbus Leonardi e considerazioni sulla sua posizione generica, con note su Puto Signoret. Bollettino del Laboratorio di Entomologia Agraria 'Filippo Silvestri', Portici, 42, 212-219.

Marotta, S. \& Tranfaglia, A. (1993) Le specie del genere Puto Signoret (Homoptera Coccoidea Pseudococcidae) del'Europa centrale e del bacino del Mediterraneo. Bollettino del Laboratorio di Entomologia Agraria 'Filippo Silvestri', Portici, 48, $171-205$.

Marotta, S. \& Tranfaglia, A. (1995) Variability of morphological characters and its use in the systematics of mealybugs (Homoptera: Pseudococcidae). Israel Journal of Entomology, 29, 67-73.

Matesova, G.I. (1957) [New species of coccids (Homoptera, Coccoidea) from southeastern Kazakhstan.] (in Russian) Entomologicheskoe Obozrenye, 36, 163-174.

McKenzie, H.L. (1960) Taxonomic study of California mealybugs with descriptions of new species (Homoptera: Coccoidea: Pseudococcidae). Hilgardia, 29, 681-770.

McKenzie, H.L. (1967) Mealybugs of California with taxonomy, biology, and control of North American species (Homoptera: Coccoidea: Pseudococcidae). University of California Press, Berkeley, 526 pp.

Miller, D.R. (1975) A revision of the genus Heterococcus Ferris with a diagnosis of Brevennia Goux (Homoptera: Coccoidea: Pseudococcidae). United States Department of Agriculture Technical Bulletin, 1497, 1-61.

Miller, D.R. (1984) Phylogeny and classification of the Margarodidae and related groups (Homoptera: Coccoidea). Proceedings of the 10th International Symposium of Central European Entomofaunistics, Budapest, 15-20 August 1983, 321-324.

Miller, D.R. (1991) The scales, scale insects or coccoids, In: Stehr, F.W. (Ed.), Immature Insects, Volume 2. Kendall/Hunt Publishing Company, Iowa, pp. 90-117.

Miller, D.R. \& Appleby, J.E. (1971) A redescription of Phenacoccus dearnessi (Homoptera: Coccoidea: Pseudococcidae). Annals of the Entomological Society of America, 64, 1342-1357.

Miller, D.R. \& Kosztarab, M. (1979) Recent advances in the study of scale insects. Annual Review of Entomology, 24, 1-27.

Miller, D.R. \& Miller, G.L. (1993a) Description of a new genus of scale insect with a discussion of relationships among families related to the Kermesidae (Homoptera: Coccoidea). Systematic Entomology, 18, 237-251.

Miller, D.R. \& Miller, G.L. (1993b) A new species of Puto and preliminary analysis of the phylogenetic position of the Puto group within the Coccoidea (Homoptera: Coccoidea). Jeffersoniana: Contributions from the Virginia Museum of Natural History, 4, 1-35.

Miller, D.R., Miller, G.L. \& Watson, G.W. (2002) Invasive species of mealybugs (Hemiptera: Pseudococcidae) and their threat to U.S. agriculture. Proceedings of the Entomological Society of Washington, 104, 825-835.

Miller, G.L. \& Williams, M.L. (2002) Systematics of the adult male soft scales from America north of Mexico (Hemiptera: Coccidae). Contributions on Entomology, International, 5, 53-126.

Morrison, H. (1927) Descriptions of the genera and species belonging to the coccid family Margarodidae. Proceedings of the Biological Society of Washington, 40, 99-109.

Morrison, H. (1928) A classification of the higher groups and genera of the coccid family Margarodidae. Technical Bulletin United States Department of Agriculture, 52, 1-239.

Morrison, H. (1952) Classification of the Ortheziidae. Supplement to "Classification of scale insects of the subfamily Ortheziinae." United States Department of Agriculture Technical Bulletin, 1052, 1-80.

Nasonov, N.V. (1908) Steingelia gorodetskia, nov. gen. et nov. sp. nouveau genre et espèce des coccides du groupe Xylococcini. Annuaire du Musée Zoologique de l'Académie Impériale des Sciences de St. Pétersbourg, 13, 345-352.

Normark, B.B. (2003) The evolution of alternative genetic systems in insects. Annual Review of Entomology, 48, $397-423$.

Nur, U. (1980) Evolution of unusual chromosome systems in scale insects (Coccoidea: Homoptera). In: Blackman, R.L., Hewitt, G.M. and Ashburner, M. (Eds). Insect Cytogenetics, Symposia of the Royal Entomological Society of London, 10, 97-117.

Reyne, A. (1954) A redescription of Puto antennatus Sign. (Homoptera: Coccoidea) with notes on Ceroputo pilosellae Šulc and Macrocerococcus superbus Leon. Zoologische Mededelingen, 32, 291-324.

Ross, L., Pen, I. \& Shuker, D.M. (2010) Genomic conflict in scale insects: the causes and consequences of bizarre genetic systems. Biological Reviews, 85, 807-828.

Schumacher, F. (1917) Eine neue Schildlaus aus Brandenburg. Zeitschrift für Deutsche Entomologen, 4, 429-430.

Signoret, V. (1875) Essai sur les cochenilles ou gallinsectes (Homoptères - Coccides), 15e partie. Annales de la Société entomologique de France (série 5), 5, 305-352.

Signoret, V. (1876) Essai sur les cochenilles ou gallinsectes (Homoptères - Coccides) 17e partie. Annales de la Société entomologique de France (série 5.), 5, 374-394.

Sternlicht, M. (1969) Kermes bytinskii n. spec. (Coccoidea, Kermesidae) in Israel and observations on its life history. Israel Journal of Entomology, 4, 251-270.

Šulc, K. (1898) Studie o coccidech. -II. Sitzungsberichte der K. Bohmisch Gesellschaft der Wissenschaften (1897) 66, 1-19. 
Takahashi, R. (1932) Records and descriptions of the Coccidae from Formosa. Part 2. Journal of the Society of Tropical Agriculture Formosa, 4, 41-48.

Tang, F.D. (1992) The Pseudococcidae of China (Homoptera: Coccinea of Insects). Beijing, Chinese Agricultural Science Technology Press, 767 pp.

Tereznikova, E.M. (1975a) Coccids, Issue 18, Scale insects, gigantic scales and mealybugs, Ortheziidae, Margarodidae, Pseudococcidae. Fauna Ukraini, 20, 295 pp.

Tereznikova, E.M. (1975b) [About the synonymy of two coccoid species.] (In Russian) Vestnik Zoologii. Institut Zoologii Akademiya Nauk Ukrainskoi SSR. Kiev, No. 4, 32.

Theron, J.G. (1958) Comparative studies on the morphology of male scale insects. (Hemiptera: Coccoidea). Annals of the University of Stellenbosch, 34, 1-71.

Vayssière, P. (1923) Un nouveau coccide (Hem.) de la faune Africaine. Bulletin de la Société Entomologique de France, 11/12, 152-55.

Vayssière, P. (1927) Sur quelques Coccidae (Hem.) de l'Afrique du Nord. Bulletin de la Société Entomologique de France, 6 , 107-111.

Washburn, R.I. (1965) Description and bionomics of a new species of Puto from Utah (Homoptera: Coccoidea: Pseudococcidae). Annals of the Entomological Society of America, 58, 203-297.

Williams, D.J. (2004) Mealybugs of Southern Asia. The Natural History Museum, London, U.K. and Southdene SDN, BHD, Kuala Lumpur, Malaysia, 896 pp.

Williams, D.J. \& Granara de Willink, C.M. (1992) Mealybugs of Central and South America. Wallingford, U.K., CAB International, $635 \mathrm{pp}$.

Yokogawa, T. \& Yahara, T. (2009) Mitochondrial phylogeny certified PGL (paternal genome loss) is of single origin and haplodiploidy sensu stricto (arrhenotoky) did evolve from PGL in the scale insects (Hemiptera: Coccoidea). Genes and Genetic Systems, 84, 57-66.

Zacharuk, R.Y. \& Shields, V.D. (1991) Sensilla of immature insects. Annual Review of Entomology, 36, 331-354. 